\title{
A Case of Platyspondylic Lethal Skeletal Dysplasia Torrance Type
}

\author{
Sung Chan Lee, and Min Seon Choi \\ Department of Pediatrics, Chosun University College of Medicine, Gwangju, Korea
}

\section{ABSTRACT}

Platyspondylic lethal skeletal dysplasia, Torrance type (PLSD-T), is one of the phenotypes of type II collagenopathy and is characteristic of severe bone growth disorder. This phenotype may limit the growth and expansion of the lungs, which is known to cause death from respiratory failure during or shortly after birth, but in few less severe cases, patients have been reported to have survived to adulthood. We have experienced a case of PLSD-T in a preterm infant who was delivered via cesarean section at the gestational age of 29 weeks 3 days, with a birth weight of $1.15 \mathrm{~kg}$. Physical examination of the infant revealed characteristic findings of short arms and legs, small thorax, distended abdomen, and cleft palate. On the basis of the subsequent genetic testing, the patient had a heterozygous mutation in the encoded c-propeptide region of collagen, type II, alpha 1 (COL2A1), c.4335G >A (p.Trp1445*) in exon 52. This is the first case of PLSD-T diagnosed in Korea, and we hereby report the case.

Key Words: Platyspondylic lethal skeletal dysplasia, Torrance type, PLSD-T, Type II collagen, COL2A1

서론

Platyspondylic lethal skeletal dysplasia, Torrance type (PLSD-T)는 제 2형 교원질병의 임상표 현형의 하나로 심각한 골형성 장애를 특징으로 하는 질환으로 2012년까지 전 세계적으로 5건의 증례에서 18 명의 환자가 보고된 매우 드문 질환이다 ${ }^{1-5)}$.

Collagen, type II, alpha 1 (COL2A1), 유전자는 연골 및 눈의 유리체에서 발견되는 섬유소 교 원질인 제 2 형 Homotrimeric 콜라겐의 alpha 1 사슬을 암호화 한다. 많은 임상 표현형들은 대부 분 COL2A1 유전자의 이형 접합 돌연변이에서 발생 하게 되며, COL2A1 유전자의 돌연변이로 인 한 질환을 통틀어 제 2형 교원질병이라 부른다. 임상표현형은 Stickler dysplasia type I (STD-1), Kinest dysplasia (KND), achondrogenesis type II (ACG II), hypochondrogenesis(HCG), several spondyloepiphyseal dysplasia (SED), SED congenital (SEDC), SED late onset (SEDT), PLSD-T, spondyloperipheral dysplasia (SPPD), vitreorntinopathy and phalangeal epiphyseal dysplasia (VPED) 등이 있으며 STD-1과 SED가 그 중에 잘 알려진 편이다). Stickler dysplasia type I (STD1)의 빈도는 $1 / 10,000$ 으로 추정되나, 그 외 흔하지 않은 제 2 형 교원질병의 유병률은 잘 알려져
Received: 14 September 2017

Revised: 19 October 2017

Accepted: 22 October 2017

Correspondence to: Min Seon Choi Department of Pediatrics, Chosun University Hospital, Chosun University College of Medicine, 365 Philmun Daero, Donggu, Gwangiu 61453, Korea

Tel: +82-62-220-3053

Fax: +82-62-227-2904

E-mail:mschoi@chosun.ac.kr

Copyright(c)

By Korean Society of Neonatology.

All right reserved.

This is an Open-Access article distributed under the terms of the Creative Commons Attribution Non-Commercial License (http://creativecommons.org/licenses/ by-nc/4.0), which permits unrestricted non-commercial use, distribution, and reproduction in any medium, provided the original work is properly cited. 
있지 않다. PLSD-T는 1979년 Horton 등에 의해 처음 기술된 ${ }^{6)}$ 이래 2012년까지 전 세계적으로 5건의 증례에서 18명의 환자가 보고된 매우 드문 질환이다.

그리고 대부분의 임상 표현형들은 COL $2 A 1$ 유전자의 삼중 나선 도메인의 과오돌연변이(missense mutation) 혹은 in-frame derangement와 관련되어 있으나 ${ }^{3,7)}$, 흔하지 않은 임상표현형들(PLSD-T, $\mathrm{SPPD}, \mathrm{VPED})$ 의 경우는 C-propeptide 도메인의 변이와 연관되어 있 으며, 과오돌연변이(missense mutation)를 통해 일반적으로 상염색 체 우성 유전을 나타낸다 ${ }^{1,8-10)}$.

PLSD-T는 1979년 Horton 등에 의해 처음 기술되었으며 드문 골격 이형성증으로 편평 척추, 매우 짧은 사지, 심각한 폐의 저형성, 그리 고 단지증을 특징으로 한다. PLSD-T는 특징적으로 영상학적 검사에 서 다양한 형태의 편평척추, 짧은 갈비뼈, 짧은 늑골, 하부 장골의 저 형성, 방사형 골간단을 보인다 ${ }^{6,11,12)}$.

일반적으로 주산기에 치명적이지만 출생시 동반된 기형의 정도 에 따라서 장기 생존자가 보고 된바 있으며, 환자의 2세에서 같은 변 이가 발견된 사례 역시 함께 보고되었다, ${ }^{2,45}$.

저자들은 아직 국내에 보고되지 않은 COL2A1 gene mutation 이 확인되어 PLSD-T 로 진단된 재태연령 29주 3일 미숙아를 경험하였 기에 보고하는 바이다.

\section{증례}

재태연령 29주 3 일, 출생체중 $1.15 \mathrm{~kg}$ 으로 제왕절개로 태어난 둘 째 아이로 여아였으며, 첫째 아이는 만 3세 여아로 건강하였고, 가족 력에서 다른 근골격계 이상 질환은 없었다. 임신 25주에 시행한 태 아 초음파에서 Femur의 길이는 각각 $2.5 \mathrm{~cm}$ 였으며, 이는 18 주 태아 의 평균 길이와 비슷한 수준이었다 ${ }^{13)}$. 출생 시 아프가 점수는 1 분에 3점, 5 분에 5점이었으며, 호흡곤란이 지속되어 기관내 삽관 후 계면 활성제를 투여 하였다. 말초 혈액 검사에서 혈색소 $15.7 \mathrm{~g} / \mathrm{dL}$, 백혈 구 $9,120 / \mathrm{mm}^{3}$, 혈소판 $292,000 / \mathrm{mm}^{3}$ 이었으며, 정맥혈가스분석에 서 $\mathrm{pH} 7.342, \mathrm{pCO}_{2} 38.9 \mathrm{mmHg}, \mathrm{pO}_{2} 47.7 \mathrm{mmHg}, \mathrm{HCO}_{3} 21.3 \mathrm{mmol} /$ $\mathrm{L}, \mathrm{SPO}_{2} 80.5 \%$ 였다. 신체검사에서 몸통에 비해 짧은 팔다리와 작 은 흥곽, 튀어나온 배, 구개열이 관찰되었고(Figures 1A,1B), 체중 $1.15 \mathrm{~kg}$ (10-25 p), 신장 $32.5 \mathrm{~cm}(<10 \mathrm{p})$, 두위 $28 \mathrm{~cm}(50-75 \mathrm{p})$ 였 다. 환자는 신생아 호흡곤란증후군으로 기계환기 치료를 지속 하였 으며, 교정연령 36 주에도 $\mathrm{FiO}_{2} 35 \%$ 이상 요구하며, 기계환기가 필요 한 상태로 중증 기관지폐이형성증으로 진단하였다. 출생 3 일째 시 행한 뇌초음파에서 뇌실 확장 및 뇌실내 출혈 소견은 확인되지 않았 고, 9일째 시행한 심장초음파에서 이상소견은 보이지 않았다. 19일 째 양쪽의 1 단계 뇌실내 출혈이 관찰되었으며, 75 일째 양쪽 뇌실의 확장을 보였다. 출생 66일째인 재태연령 38주 6일에 시행한 안과검
사에서 미숙아 망막병증(retinopathy of prematurity, ROP)은 보이 지 않고 정상이었다. 몸통에 비해 짧은 팔다리와 작은 흥곽, 튀어나 온 배, 구개열 등의 선천기형평가를 위해 일차적으로 가장 흔한 원 인인 연골무형성증 여부 확인 위해 FGFR3 유전자 검사를 시행 하였 으나 변이는 발견되지 않았으며, 골격 이형성증(Skeletal dysplasia) 등의 제 2형 교원질병이 의심되어 Diagnostic Exome sequencing (DES) 을 검사하였다. DES에서 COL2A1 유전자의 1445번째 아미노 산인 Tryptophan이 stop codon으로 치환되는 nonsense variation을 보였으며(Figure 2), 이는 PLSD-T 환자에서 pathogenic variant로 보 고된 바가 있었다 ${ }^{2)}$. 부모에서는 유전자 변이를 보이지 않아 산발적

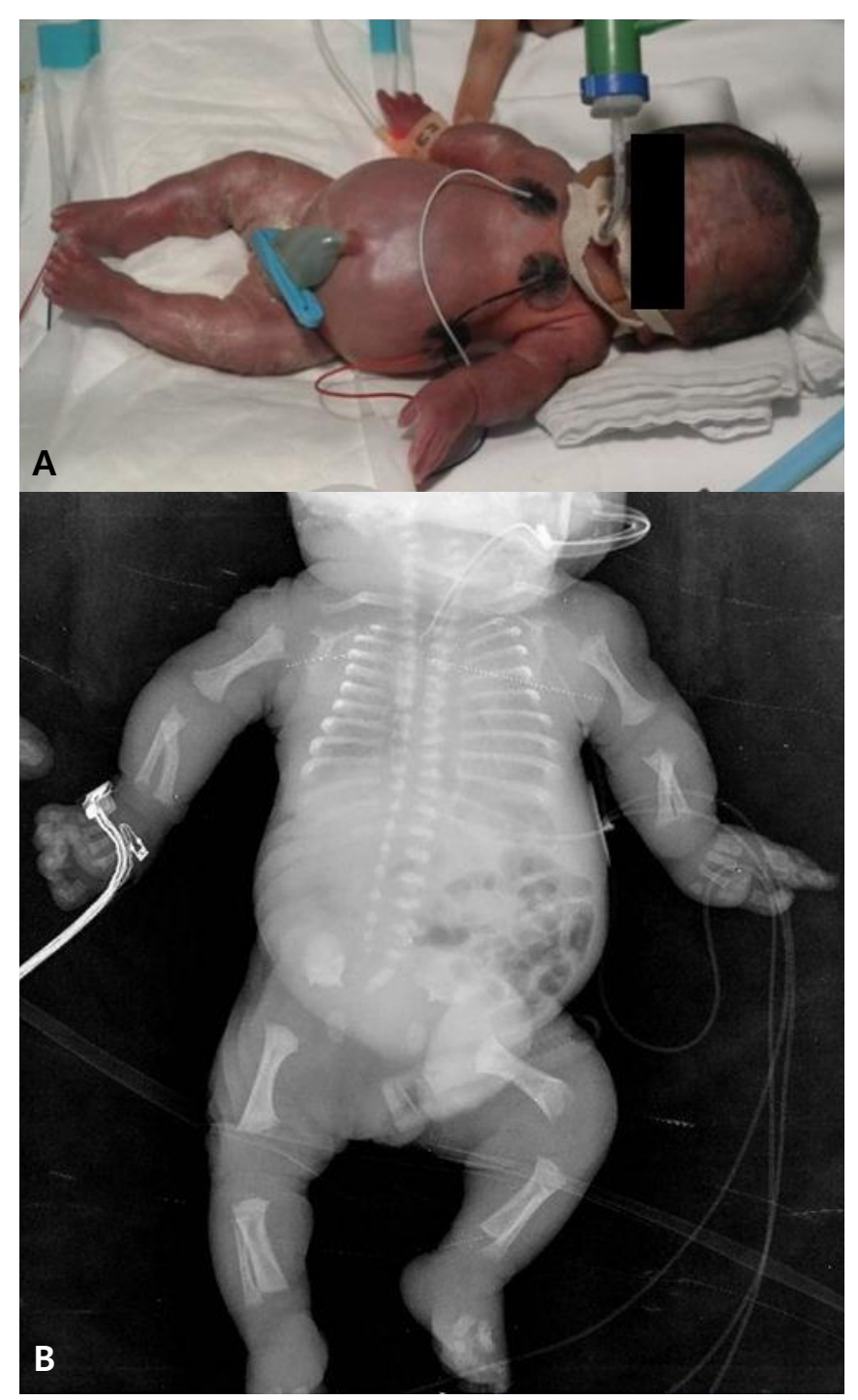

Figure 1. (A) Gross appearance shows typically shortening of upper \& lower extremities, small chest and protruded abdomen (at birth). (B) Infantogram shows wafer-thin vertebral bodies, short ribs with splayed ends, shortened long bones with splayed metaphyseal margins (at birth). 


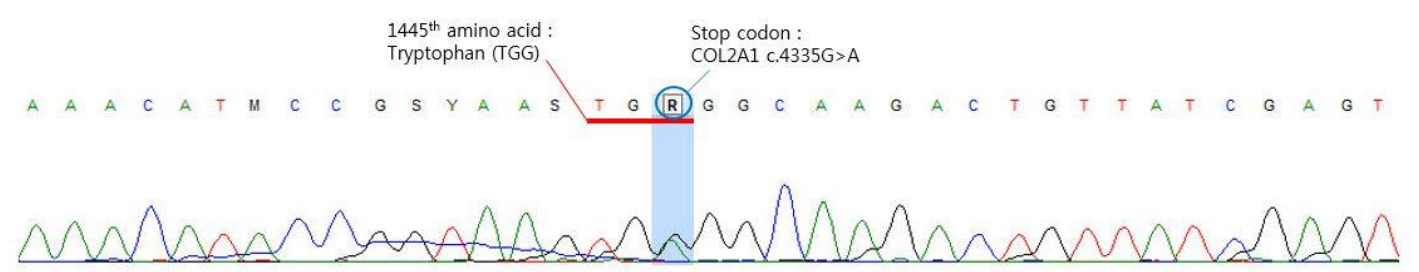

Figure 2. Collagen, type II, alpha 1 (COL2A1) analysis shows nonsense mutation in the encoded C-propeptide region of COL2A1, c.4335G >A (p.Trp1445*) that results in a tryptophan (Trp) to stop codon substitution.

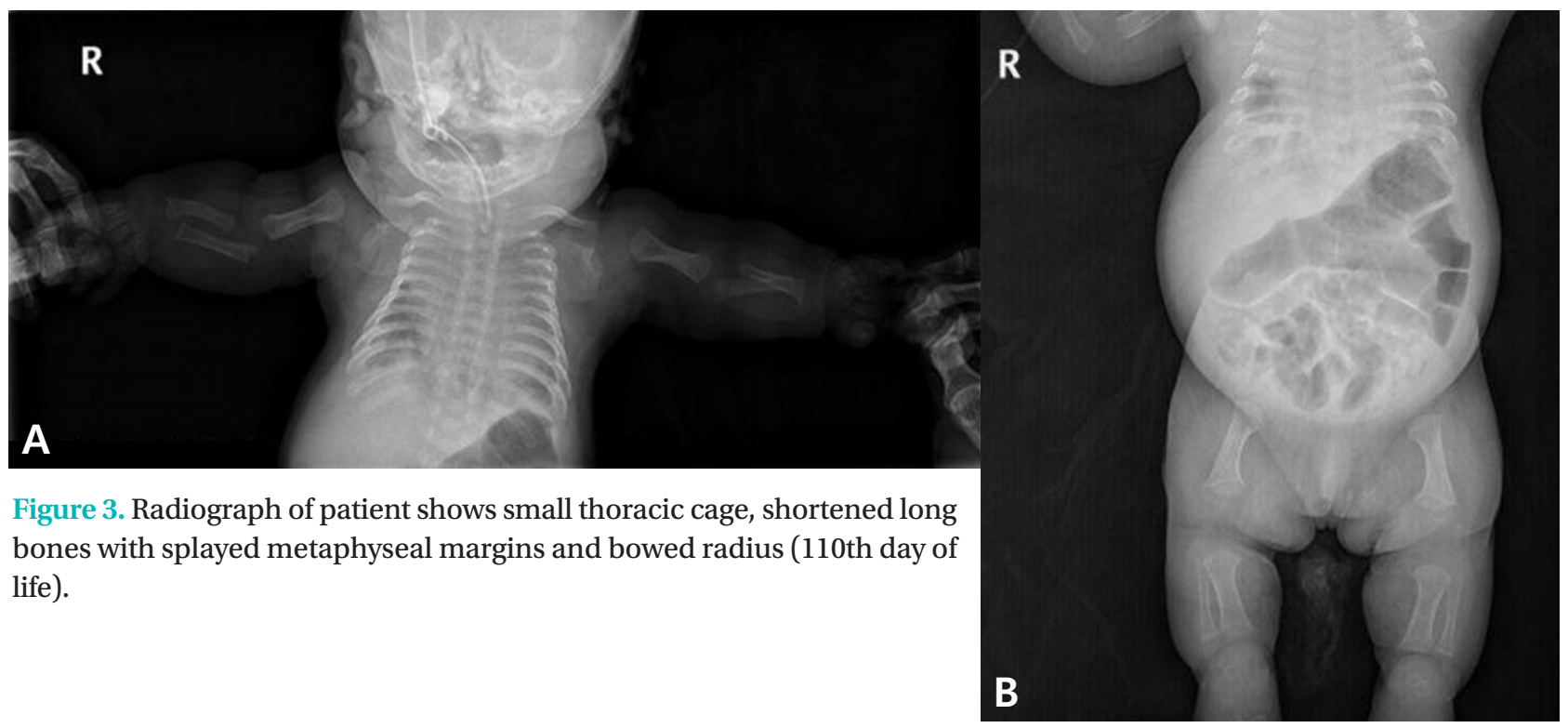

인 경우(sporadic case)로 판단하였다. 상대적으로 짧은 팔다리, 편 평한 척추 몸통, 갈비뼈의 성장미숙과 이로 인한 작은 흥곽, 비전형 적인 골간단, 노뼈의 휘어짐 등의 임상양상(Figures $3 \mathrm{~A}, 3 \mathrm{~B}$ ) 및 제 2 형 교원질의 carboxyl propeptide의 변이를 통해 PLSD-T로 진단 하 였다. 기계환기 치료중 출생 38 일째 점차 기계환기 치료에서 이탈 하여 비침습적양압환기(Non invasive positive pressure ventilation, $\mathrm{NIPPV}$ 로 변경 하였으나 함몰 호흡 및 고탄산혈증이 반복되어 기계 환기와 비침습적양압환기로 교대 치료를 반복 하였고 호흡곤란이 지속되어 출생 55 일째부터 다시 $\mathrm{FiO}_{2} 35 \%$ 로 기계환기 치료를 시작 하였다. 기계환기 치료중에 산소요구량이 점차 증가하고 출생 85 일 째 부터 $\mathrm{FiO}_{2} 100 \%$ 로 산소 치료를 함에도 산소 포화도 잘 유지 되지 않는 모습 반복되었다. 출생 136일째부터 심박수 및 산소포화도가 함께 떨어지는 양상으로 저산소증이 반복되어 심폐소생술을 시행하 였고, 3 분 이내의 심폐소생술 후 회복되는 양상이었으나, 출생 151 일째 30분 동안 강직간대발작이 지속되었으며, amplitude integrated electroencephalography (aEEG)에서도 경련 양상이 지속되어 항경 련제(Phenobarbital)를 투여하였다. 이후 경련 조절은 잘되었으나, 출생 170 일째 심박동수 60 회 이하 및 산소포화도 $60 \%$ 이하 지속되
어 약 6 분간 심폐소생술을 시행 후 회복되었다. 171 일째 움직임 감 소되고, 자발호흡이 없고 통증에 반응 보이지 않았으며, $\mathrm{aEEG}$ 에서 전반적으로 최저와 최대 진폭 모두 $5 \mu \mathrm{V}$ 이하로 저하되어 있었고 raw EEG에서도 폭이 일정하며, 비활성화된 양상 확인되고 동공반사 보이지 않아 반복되는 저산소증으로 인한 뇌 손상으로 판단 하였으 며, 보호자에게 환자의 상태 설명 후 연명 치료 중지에 대한 동의를 얻었다. 환자는 출생 후 174 일, 교정연령 3 개월 10 일째 사망하였다.

\section{고찰}

PLSD-T는 제 2형 교원질병의 하나로 12 번 유전자에 존재하는 COL2A1 유전자의 이질성 돌연변이에 의한다 ${ }^{7,9)}$.

제 2 형 교원질병의 임상 증상은 제 2 형 교원질의 기능과 연관되어 있는데, 제 2형 교원질은 연골의 주 구성성분으로 연골의 기본 구조 를 형성하는 것이 주 기능이며, 연골내 골형성에 있어서도 중요한 역 할을 한다. 장골과 추체의 연골 형성 장애로 저신장을 초래하고, 편 평척추, 골반의 골화 지연, 골간단 골격 지연 등 골간단의 이상을 보 
인다. 특징적인 얼굴 모습으로는 함몰된 비교로 인해 편평한 안면과 짧은 목을 보이고 제 2형 교원질이 발생학 적으로 주된 역할을 하는 구개, 초자체액, 시신경 망막 세포 및 내이세포에 장애를 초래하여 구개열이나 망막병증, 망막의 박리, 유리막병증과 난청의 조기 발병 을 초래한다 ${ }^{7,14}$. 그리고 선천적 소하악증, 설근의 침하와 구개열을 특징으로 하는 Pierre Robin sequence 가 동반되었을 경우에도 제 2 형 교원질병을 의심해 볼 수 있다.

대표적인 제 2형 교원질병의 임상 표현형으로 ACG II, HCG, SEDC, SPPD, Kniest dysplasia, Skickler syndrome type I, PLSD-T, VPED가 있으며 ${ }^{3)}$ 간단히 살펴 보면, ACG II는 지연된 연골내 골화로 인해 짧 은 팔과 다리, 짧은 늑골과 작은 흉부 미성숙한 폐와 돌출된 이마, 작 은턱이 특징적이며 구개열을 동반하며 상대적으로 손과 발 모양은 정상적이다. HCG는 ACG와 비슷하나 보다 경하며, 목과 골반의 일 부인 척추골이 부분적으로 골화가 되지 않으며, 얼굴은 편평하고 타 원형이며 넒은 미간과 작은 턱이 특징적이고 구개열을 동반 하기도 한다. SEDC는 장골 원위부의 골화 지연, 치골 및 근위골의 골화 결 절을 특징으로 하며 시력과 청력에도 영향을 미친다. SPPD는 골화 의 장애로 편평한 척추뼈, 비정상적으로 짧은 손발가락이 특징적이 며, 근시 및 청력소실, 정신지체를 동반하기도 한다. PLSD-T는 드물 고 치명적인 골격 이형성증으로 편평 척추, 매우 짧은 사지, 심각한 폐의 저형성이 특징적이다.

$C O L 2 A 1$ 유전자의 돌연변이 형태와 임상 표현형사이의 상호관계 는 명확하지 않으나 유전자의 돌연변이 형태에 따라 분류를 하면, $\mathrm{ACG} / \mathrm{HCG} / \mathrm{SEDC}$ 는 $\mathrm{COL} 2 \mathrm{A1}$ 유전자의 3중 나선형 영역에서의 과오 돌연변이(missense mutation) 혹은 in-frame derangement로 발생하 며 ${ }^{3)}$, Kniest dysplasia는 Exon skipping 에 의하며, Stickler dysplasia 는 단상부족(Haploinsufficiency)에 의해 주로 발생하는 것으로 알 려져 있다. 반면에 PLSD-T/SPPD는 COL2A1 유전자의 C-propeptide 영역에서의 변이에 의해 발생한다 ${ }^{8,10)}$.

대부분의 Type II collagenopathy는 C-peptide영역에서의 변이는 드물며 주로 3중 나선 구조의 이상에서 발현되므로 다른 아형들과 SPPD, PLSD-T를 감별하는 가장 중요한 감별점이 될 수 있다 ${ }^{8-10)}$.

PLSD-T는 대부분이 상염색체 우성 유전을 따른다고 알려져 있 으나 정상 표현형의 부모에서 발생하는 산발적인 경우도 드물게 보 고 되어있다. 산발적인 발생의 경우는 대부분이 새로 생긴 돌연변이 (de novo mutation)에 의한 경우이나 형제에서 같은 질환이 동반되 는 경우에는 생식세포 모자이크현상(germline mosaicism)도 있을 수 있다 ${ }^{11)}$. 본 증례의 환자의 경우는 부모의 유전자 검사에서 이상 을 보이지 않았고, 형제에서도 질환이 동반되지 않은 산발적인 증례 (sporadic case)로 생각된다.

$\mathrm{SPPD}$ 와 PLSD-T 는 둘다 중심부 저형성증, 요추 및 대퇴부의 형성 부전, 짧은 다리, 편평하고 얇은 척추가 특징적이고 PLSD-T가 보다 드물며 치명적이나, 상대적으로 손발가락의 변형은 드물다고 알려
져 있다. 또한 PLSD-T는 주산기에 치명적이지만 출생시 동반된 기 형의 정도에 따라서 장기 생존자가 보고 된바 있으며, 이를 SPPD의 실례로 보고하기도 하였다. 따라서 PLSD-T와 SPPD는 제 2형 교원질 병 중에서도 연속선상의 스펙트럼을 구성하는 질환이라고 볼 수 있 다 ${ }^{2)}$.

제 2형 교원질병은 출생 전 시기에 자궁 내에서 저명한 편평한 척 추, 짧은 팔다리와 좁은 흥곽이 확인되는데 이는 제 1 형 연골무형성 증(achondroplasia type 1), 골형성부전증(Osteogenesis imperfecta), 저인산증과 감별이 필요하다. 또한 Thanatophoric dysplasia (TD) 는 편평척추뼈를 동반하는 치명적인 골격 이형성증으로 과거에 는 PLSD-T와 임상 증상이 유사하여 PLSD-T가 처음 보고되던 시기 에 $\mathrm{TD}$ 의 아형으로 도 생각되었다. 그러나 유전자 분석에서 $\mathrm{TD}$ 는 FGFR-3 유전자의 과오돌연변이에 의한 것으로 둘은 전혀 다른 독립 된 질환으로 분류되었으며, $\mathrm{TD}$ 에서는 제 2형 교원질병에서는 보이 지 않는 두개골의 이상이 발견되기도 한다. 연골무형성증은 FGFR-3 유전자의 점 돌연변이에 의한 연골 내 골화의 장애가 원인이며, 근위 부의 골이 주로 짧아져 있는 것(rhizomelic short limp)이 특징이다. 골형성 부전증은 제 1 형 교원질을 규정하는 유전자의 변이가 원인이 고, 넓은 이마와 삼각형 모양의 두부가 특징적이다. 또한 공막, 치아 의 상아질, 내이, 피부등에서도 교원질의 이상 증상이 동반되며, 주 증상은 주로 대퇴골과 경골의 반복되는 골절이다 ${ }^{15-17)}$.

국내에서는 아직 PLSD-T 에 대한 보고는 없었으며, 국외 연구에 서도 상당수가 사후에 영상검사 및 유전자 검사가 진행 된 것에 비하 여, 본 증례는 재태연령 29주 3일로 출생한 미숙아에서 특징적인 골 격과 폐의 저형성, 구개열의 type II collagenopathy의 임상 증상, 영 상학적 검사 및 유전자 검사를 통해 PLSD-T를 진단하였다.

\section{REFERENCES}

1) Nishimura G, Nakashima E, Mabuchi A, Shimamoto K, Shimamoto T, Shimao Y, et al. Identification of COL2A1 mutations in platyspondylic skeletal dysplasia, Torrance type. J Med Genet 2004;41:75-9.

2) Zankl A, Neumann L, Ignatius J, Nikkels P, Schrander-Stumpel C, Mortier G, et al. Dominant negative mutations in the C-propeptide of COL2A1 cause platyspondylic lethal skeletal dysplasia, Torrance type, and define a novel subfamily within the type 2 collagenopathies. Am J Med Genet Part A 2005;133A: 61-7.

3) Okamoto T, Nagaya K, Asai H, Tsuchida E, Nohara F, Hayashi $\mathrm{T}$, et al. Platyspondylic lethal dysplasia Torrance type with a heterozygous mutation in the triple helical domain of COL2A1 in two sibs from phenotypically normal parents. Am J Med Genet A 2012;158a:1953-6. 
4) Neumann L, Kunze J, Uhl M, Stover B, Zabel B, Spranger J. Survival to adulthood and dominant inheritance of platyspondylic skeletal dysplasia, Torrance-Luton type. Pediatr Radiol 2003;33:786-90.

5) Desir J, Cassart M, Donner C, Coucke P, Abramowicz M, Mortier G. Spondyloperipheral dysplasia as the mosaic form of platyspondylic lethal skeletal dyplasia Torrance type in mother and fetus with the same COL2A1 mutation. Am J Med Genet Part A 2012;158A:1948-52.

6) Horton WA, Rimoin DL, Hollister DW, Lachman RS. Further heterogeneity within lethal neonatal short-limbed dwarfism: the platyspondylic types. J Pediatr 1979;94:736-42.

7) Spranger J, Winterpacht A, Zabel B. The type II collagenopathies: a spectrum of chondrodysplasias. Eur J Pediatr 1994;153: 56-65.

8) Zabel B, Hilbert K, Stoss H, Superti-Furga A, Spranger J, Winterpacht A. A specific collagen type II gene (COL2A1) mutation presenting as spondyloperipheral dysplasia. Am J Med Genet 1996;63:123-8.

9) Richards AJ, Morgan J, Bearcroft PW, Pickering E, Owen MJ, Holmans $\mathrm{P}$, et al. Vitreoretinopathy with phalangeal epiphyseal dysplasia, a type II collagenopathy resulting from a novel mutation in the C-propeptide region of the molecule. J Med Genet 2002;39:661-5.

10) Zankl A, Zabel B, Hilbert K, Wildhardt G, Cuenot S, Xavier B, et al. Spondyloperipheral dysplasia is caused by truncating mutations in the C-propeptide of COL2A1. Am J Med Genet Part A 2004;129A:144-8.

11) Kaibara N, Yokoyama K, Nakano H. Torrance type of lethal neonatal short-limbed platyspondylic dwarfism. Skeletal Radiol 1983;10:17-9.

12) Freisinger $P$, Bonaventure J, Stoess $H$, Pontz BF, Emmrich $P$, Nerlich A. Type II collagenopathies: are there additional family members? Am J Med Genet 1996;63:137-43.

13) Lyn S. Douglas G. Chart of fetal size : limb bones. BJOG 2002; 109:919-29.

14) Yoo HJ, Park SE, Park SO, Park JH, Kim SY. A case of sponduloepiphyseal dysplasia congenital. Korean J Pediatr 1997;40:71620.

15) Tamaru S, KiKuchi A, Takagi K, Wakamatsu M, Ono K, Horikoshi T, et al. Prenatal diagnosis of platyspondylic skeletal dysplasia Torrance type with three-dimensional helical computed tomography. Prenat Diagn 2009;29:1282-4.

16) Brodie SG, Kitoh H, Lachman RS, Nolasco LM, Mekikian PB, Wilcox WR. Platyspondylic lethal skeletal dysplasia, San Diego type, is caused by FGFR3 mutations. Am J Med Genet 1999;84:476-80.

17) Kannu P, Bateman J, Savarirayan R. Clinical phenotypes associated with type II collagen mutation. J Paediatr Child Health. 2012;48:E38-43. doi:10.1111/j.1440-1754.2010.01979.x. 